\title{
The Impact of Beta Blockers on Survival in Heart Transplant Recipients: Insights from the Zabrze HTx Registry
}

\author{
Grzegorz M. Kubiak $\mathbb{D}^{1,}{ }^{1,2}$ Radosław Kwieciński, ${ }^{1}$ Agnieszka Ciarka, ${ }^{2}$ \\ Andrzej Tukiendorf $\mathbb{D}^{3}{ }^{3}$ Piotr Przybyłowski, ${ }^{1}$ Tomasz Hrapkowicz, ${ }^{1}$ \\ and Michał O. Zembala ${ }^{1}$ \\ ${ }^{1}$ Department of Cardiac Vascular and Endovascular Surgery and Transplantology, Silesian Centre for Heart Diseases, \\ Medical University of Silesia, Zabrze, Poland \\ ${ }^{2}$ Department of Cardiovascular Diseases, Catholic University of Leuven, Leuven, Belgium \\ ${ }^{3}$ Department of Public Health, Wrocław Medical University, Wrocław, Poland
}

Correspondence should be addressed to Grzegorz M. Kubiak; greg_kubiak@yahoo.com

Received 31 March 2020; Accepted 16 June 2020; Published 23 July 2020

Academic Editor: Michael S. Wolin

Copyright (c) 2020 Grzegorz M. Kubiak et al. This is an open access article distributed under the Creative Commons Attribution License, which permits unrestricted use, distribution, and reproduction in any medium, provided the original work is properly cited.

\begin{abstract}
Introduction. The data assessing the impact of beta blocker (BB) medication on survival in patients after heart transplantation $(\mathrm{HTx})$ are scarce and unequivocal; therefore, we investigated this population. Methods. We retrospectively analyzed the HTx Zabrze Registry of 380 consecutive patients who survived the 30-day postoperative period. Results. The percentage of patients from the entire cohort taking BBs was as follows: atenolol 24 (17\%), bisoprolol 67 (49\%), carvedilol 11 (8\%), metoprolol 28 (20\%), and nebivolol 8 (6\%). The patients receiving BBs were older ( $56.94 \pm 14.68$ years vs. $52.70 \pm 15.35$ years, $p=0.008)$ and experienced an onset of HTx earlier in years $(11.65 \pm 7.04$ vs. $7.24 \pm 5.78 p \leq 0.001)$. They also had higher hematocrit $(0.40 \pm 0.05$ vs. $0.39 \pm 0.05$, $p=0.022)$ and red blood cells $\left(4.63\left(10^{6} / \mu \mathrm{l}\right) \pm 0.71 \mathrm{vs} .4 .45\left(10^{6} / \mu \mathrm{l}\right) \pm 0.68, p=0.015\right)$. Survival according to BB medication did not differ among the groups $(p=0.655)$ (log-rank test). Univariate Cox proportional hazard regression analysis revealed that the following parameters were associated with unfavorable diagnosis: serum concentration of albumin (g/l) $\mathrm{HR}$ : $0.87,95 \% \mathrm{CI}$ (0.81-0.94), $p=0.0004$; fibrinogen (mg/dl) HR: 1.006, 95\% CI (1.002-1.008), $p=0.0017$; and C-reactive protein (mg/l) HR: 1.014, 95\% CI (1.004-1.023), $p=0.0044$. Conclusions. The use of BBs in our cohort of patients after HTx was not associated with survival benefits.
\end{abstract}

\section{Introduction}

Heart transplantation (HTx), which is the gold standard of treatment at the end stage of heart failure, is associated with denervation of the donor's heart. Since the reinnervation is reported in approximately fifty percent of cases and rarely affects the parasympathetic nervous system, the donors have increased heart rates $[1,2]$. Physiological studies have shown that the exercise capacity of a denervated heart is determined by the increase in stroke volume through the Frank-Starling mechanism, and the raised heart rate (HR) contributes only later, at the peak of exercise [3]. The older studies have indicated that the use of nonselective beta blocker (BB) (propranolol) during physical activity resulted in reduced exercise tolerance and capacity [3, 4]. Therefore, BBs were advised to be used with caution; nonetheless, the early concerns about their use were recently challenged. Hence, a growing body of evidence shows that the elevated $\mathrm{HR}$ is associated with increased mortality and that the use of HR-decreasing medication in the selected group of patients may improve the short- and midterm results $[5,6]$. Data on the use of BBs in HTx recipients in the clinical setting are scarce and unequivocal; therefore, we sought to investigate the impact of these drugs in the population of patients included in the institutional HTx Registry [7]. 
1.1. Aim. To test the hypothesis that HTx recipients who receive $\mathrm{BBs}$ during follow-up have a better prognosis.

\section{Methods}

A total of 380 consecutive adult patients ( $\geq 18$ years) receiving HTx at the Silesian Center of Heart Diseases between January 1, 2000, and December 31, 2018, who survived the in-hospital postoperative period and were hospitalized between May 1, 2017, and December 31, 2018, were retrospectively analyzed. The study complies with the Declaration of Helsinki and was approved by the local ethical committee which waived the need for informed consent (approval number ŚIL.KB.790.19). The follow-up between May 1, 2017, and October 31, 2019, was conducted in a typical manner in the outpatient clinic, using the phone contact or the digital information from the National Insurance System. The study flowchart is depicted in Figure 1. As the decision on the type of medication to implement was left at the physician's discretion, the authors did not interfere with this decision at any time point. The 4587 records of patients were collected using a computer software called the Retrieval Project, which was designed for this purpose. If the patient was eligible for the $\mathrm{BB}$ treatment, but it was discontinued for any reason and reported as such in a six- to twelve-month interval, the patient was described as not treated; this occurred in only three cases. The software was validated, and the data were manually verified to check if it was correctly retrieved.

2.1. Statistical Analysis. Distributions of the examined parameters were analyzed using the Shapiro-Wilk test. Categorical variables were expressed as $n$ and percentage. Continuous variables were expressed as the mean \pm standard deviation (SD). Linear variables with normal distribution were compared using Student's $t$-test. Variables with abnormal distribution were compared using the Mann-Whitney $U$ test. Categorical variables were compared using the chi-square test. A Kaplan-Meier analysis was used to demonstrate the frequency of death due to any cause during the follow-up. Log-rank test was used to compare the survival curves based on $\mathrm{BB}$ use. Cox proportional hazard uni/multivariate regression approach was used to evaluate the risk of death. Independent predictors were presented as the hazard ratio (HR) with a confidence interval (CI). Differences between the values were considered statistically significant if $p<0.05$. Analyses were performed using $\mathrm{R}$ statistical environment.

\section{Results}

The patients were more prone to receive $\mathrm{BBs}$ if they were diagnosed with supraventricular tachycardia 90 (65\%) vs. $12(5 \%)(p \leq 0.001)$ and ventricular tachycardia $14(10 \%)$ vs. $6(2 \%)(p \leq 0.001)$. BBs were also more frequently used in patients suffering from reduced left ventricular ejection fraction (LVEF) below fifty-five percent 40 (29\%) vs. 30 $(12 \%)(p \leq 0.001)$. Notwithstanding, the use of BBs among patients diagnosed with hypertension or atrial fibrillation did not differ between the groups (114 (83\%) vs. 188 (78\%),

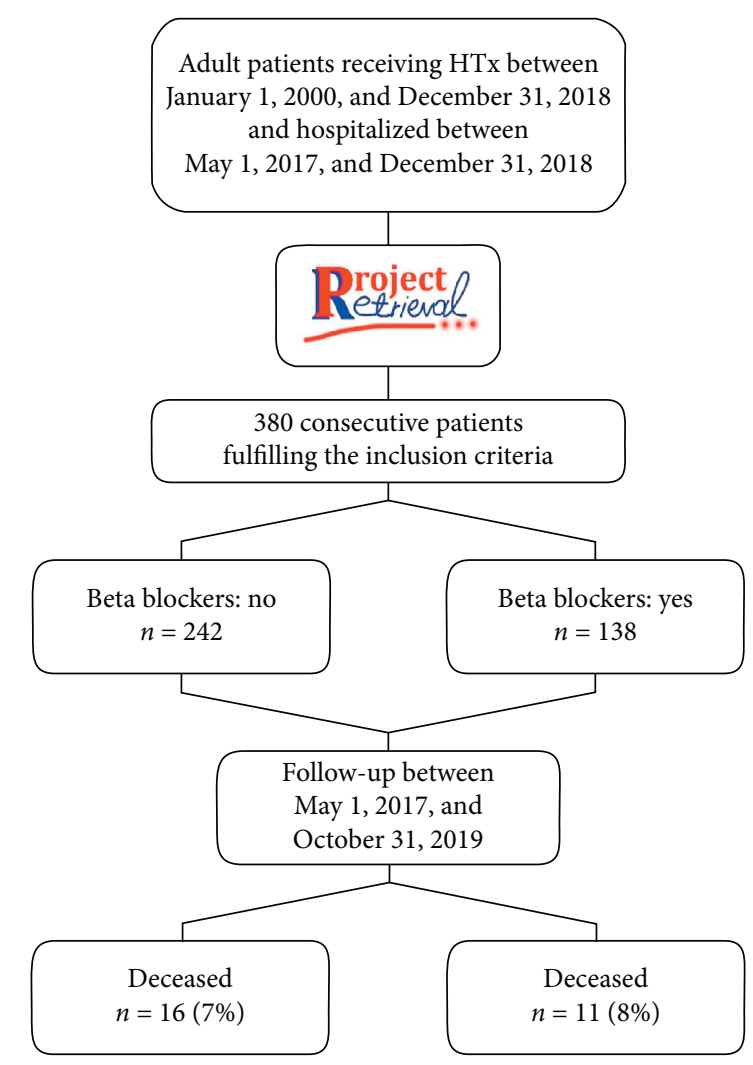

Figure 1: Flowchart of the study.

$p=\mathrm{ns}$, and $10(7 \%)$ vs. $18(7 \%), p=\mathrm{ns}$, respectively). Complex clinical characteristic (described as two or more indications) was common in both the $\mathrm{BB}$ and non- $\mathrm{BB}$ groups, $94(68 \%)$ and 54 (22\%), $p \leq 0.001$. Dilated cardiomyopathy was less frequently reported as a reason for HTx in those patients who received BBs compared to those who did not $42(30 \%)$ vs. 107 (44\%), $p=0.008$. Compared to patients who were not on $\mathrm{BBs}$, the patients receiving $\mathrm{BBs}$ were older (mean: $56.94 \pm 14.68$ years vs. $52.70 \pm 15.35$ years, $p=0.008$ ). They also had an earlier onset of HTx (mean: $11.65 \pm 7.04$ years vs. $7.24 \pm 5.78$ years, $p \leq 0.001$ ) and higher initial HR $(101.09 \pm 12.26 \quad(1 / \mathrm{min}) \quad$ vs. $90.88 \pm 12.32(1 / \mathrm{min}), p \leq 0.001)$. Other differences among the groups were statistically insignificant. The data are presented in Table 1.

Bisoprolol was used in 67 patients (49\%), carvedilol in 11 patients (8\%), metoprolol in 28 patients $(20 \%)$, and nebivolol in 8 patients $(6 \%)$. The data are depicted in Figure 2.

The patients receiving $\mathrm{BBs}$ had higher hematocrit and red blood cells than the non-BB patients $(0.40 \pm 0.05$ vs. $0.39 \pm 0.05, p=0.022$ and $4.63\left(10^{6} / \mu \mathrm{l}\right) \pm 0.71$ vs. 4.45 $\left(10^{6} / \mu 1\right) \pm 0.68, p=0.015$, respectively). They also had lower platelets: $201.73\left(10^{3} / \mu \mathrm{l}\right) \pm 62.39$ vs. $220.44\left(10^{3} / \mu \mathrm{l}\right) \pm 76.77$, $p=0.024$. Additionally, the patients receiving $\mathrm{BBs}$ had decreased level of tacrolimus $8.45(\mathrm{ng} / \mathrm{ml}) \pm 3.63$ vs. 9.40 $(\mathrm{ng} / \mathrm{ml}) \pm 3.83, p=0.037$, and cyclosporin $110.60(\mathrm{ng} / \mathrm{ml})$ \pm 32.04 vs. $141.01(\mathrm{ng} / \mathrm{ml}) \pm 49.76, p=0.033$. Other differences including differences in biochemical, hematological, and coagulation parameters were statistically insignificant. All data are shown in Table 2. 
TABle 1: Patient characteristics.

\begin{tabular}{|c|c|c|c|}
\hline & $\begin{array}{l}\text { Beta blockers: no } \\
n=242\end{array}$ & $\begin{array}{l}\text { Beta blockers: yes } \\
\qquad n=138\end{array}$ & $p$ \\
\hline Hypertension, $n(\%)$ & $188(78)$ & $114(83)$ & 0.253 \\
\hline Atrial fibrillation, $n(\%)$ & $18(7)$ & $10(7)$ & 0.945 \\
\hline Supraventricular tachycardia, $n(\%)$ & $12(5)$ & $90(65)$ & $\leq 0.001$ \\
\hline Ventricular tachycardia, $n(\%)$ & $6(2)$ & $14(10)$ & $\leq 0.001$ \\
\hline Reduced left ventricular ejection fraction $<55 \%, n(\%)$ & $30(12)$ & $40(29)$ & $\leq 0.001$ \\
\hline Two or more indications, $n(\%)$ & $54(22)$ & $94(68)$ & $\leq 0.001$ \\
\hline Age (years), mean $\pm \mathrm{SD}$ & $52.70 \pm 15.35$ & $56.94 \pm 14.68$ & 0.008 \\
\hline Women, $n(\%)$ & $53(22)$ & $32(23)$ & 0.772 \\
\hline Dilated cardiomyopathy, $n(\%)$ & $107(44)$ & $42(30)$ & 0.008 \\
\hline Ischemic cardiomyopathy, $n(\%)$ & $83(34)$ & $50(36)$ & 0.704 \\
\hline Other etiologies of heart failure, $n(\%)$ & $52(21)$ & $46(33)$ & 0.011 \\
\hline Time from HTx (years), mean \pm SD & $7.24 \pm 5.78$ & $11.65 \pm 7.04$ & $\leq 0.001$ \\
\hline Left ventricular ejection fraction (\%), mean \pm SD & $57.08 \pm 4.49$ & $55.89 \pm 5.04$ & 0.884 \\
\hline Heart rate $(1 / \mathrm{min})$, mean $\pm \mathrm{SD}$ & $90.88 \pm 12.32$ & $101.09 \pm 12.26$ & $\leq 0.001$ \\
\hline Coronary artery vasculopathy grade $0, n(\%)$ & $139(57)$ & $82(59)$ & 0.706 \\
\hline Coronary artery vasculopathy grade $1, n(\%)$ & $54(22)$ & $24(17)$ & 0.253 \\
\hline Coronary artery vasculopathy grade $2, n(\%)$ & $30(12)$ & $16(12)$ & 0.818 \\
\hline Coronary artery vasculopathy grade $3, n(\%)$ & $18(7)$ & $18(13)$ & 0.073 \\
\hline Cause of death-any cause, $n(\%)$ & $16(7)$ & $11(8)$ & 0.620 \\
\hline Cause of death-cardiovascular, $n(\%)$ & $5(2)$ & $7(5)$ & 0.107 \\
\hline Cause of death-infection, $n(\%)$ & $7(3)$ & $2(1)$ & 0.374 \\
\hline Cause of death-malignancy, $n(\%)$ & $2(1)$ & $1(1)$ & 0.914 \\
\hline Cause of death-rejection, $n(\%)$ & $1(0)$ & $1(1)$ & 0.687 \\
\hline Cause of death-other cause, $n(\%)$ & $1(0)$ & $0(0)$ & 0.450 \\
\hline Start point of BBs after $\mathrm{HTx}$ (years), mean $\pm \mathrm{SD}$, (IQR) & $\mathrm{n} / \mathrm{a}$ & $5.76 \pm 5.67(0.75-9.50)$ & $\mathrm{n} / \mathrm{a}$ \\
\hline Time duration of BBs use (years), mean $\pm \mathrm{SD}$, (IQR) & $\mathrm{n} / \mathrm{a}$ & $5.91 \pm 4.74(2.57-7.77)$ & $\mathrm{n} / \mathrm{a}$ \\
\hline Atenolol daily dose, mean \pm SD & $\mathrm{n} / \mathrm{a}$ & $43.75 \pm 11.31$ & $\mathrm{n} / \mathrm{a}$ \\
\hline Bisoprolol daily dose $(\mathrm{mg})$, mean $\pm \mathrm{SD}$ & $\mathrm{n} / \mathrm{a}$ & $4.11 \pm 2.88$ & $\mathrm{n} / \mathrm{a}$ \\
\hline Carvedilol daily dose $(\mathrm{mg})$, mean $\pm \mathrm{SD}$ & $\mathrm{n} / \mathrm{a}$ & $27.08 \pm 18.40$ & $\mathrm{n} / \mathrm{a}$ \\
\hline Nebivolol daily dose $(\mathrm{mg})$, mean \pm SD & $\mathrm{n} / \mathrm{a}$ & $3.25 \pm 1.68$ & $\mathrm{n} / \mathrm{a}$ \\
\hline Metoprolol daily dose (mg), mean $\pm S D$ & $\mathrm{n} / \mathrm{a}$ & $57.14 \pm 52.05$ & $\mathrm{n} / \mathrm{a}$ \\
\hline Angiotensin-converting enzyme inhibitors & $97(40)$ & $60(43)$ & 0.518 \\
\hline Angiotensin receptor blockers & $42(17)$ & $16(12)$ & 0.133 \\
\hline Calcium channel blocker (CCB) & $85(35)$ & $62(45)$ & 0.059 \\
\hline Dihydropyridine CCBs & $83(34)$ & $61(44)$ & 0.056 \\
\hline Non-dihydropyridine CCBs & $2(1)$ & $1(1)$ & 0.914 \\
\hline Statins & $235(97)$ & $133(96)$ & 0.695 \\
\hline Acetylsalicylic acid & $233(96)$ & $134(97)$ & 0.672 \\
\hline Ivabradine & $0(0)$ & $0(0)$ & $\mathrm{n} / \mathrm{a}$ \\
\hline Loop diuretics & $67(28)$ & $42(30)$ & 0.569 \\
\hline
\end{tabular}

SD: standard deviation; BBs: beta blockers; CCBs: calcium channel blockers; HTx: heart transplantation; IQR: interquartile range; n/a: not applicable; FU: follow-up.

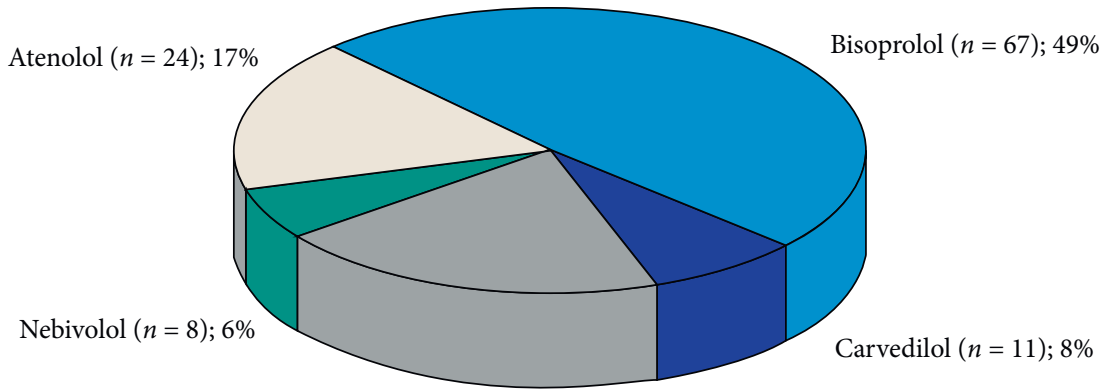

Metoprolol $(n=28) ; 20 \%$

FIGURE 2: Each type of beta blocker used in the cohort. 
TABLE 2: Laboratory findings.

\begin{tabular}{|c|c|c|c|}
\hline & $\begin{array}{c}\text { Beta blockers: no } \\
\text { Mean } \pm \text { SD } \\
n=242\end{array}$ & $\begin{array}{c}\text { Beta blockers: yes } \\
\text { Mean } \pm \text { SD } \\
n=138\end{array}$ & $p$ \\
\hline Creatinine $(\mu \mathrm{mol} / \mathrm{l})$ & $125.63 \pm 48.63$ & $134.73 \pm 64.66$ & 0.597 \\
\hline Serum glucose $(\mathrm{mmol} / \mathrm{l})$ & $6.18 \pm 2.45$ & $6.31 \pm 1.79$ & 0.622 \\
\hline Hemoglobin A1c (\%) & $5.50 \pm 0.78$ & $5.58 \pm 0.87$ & 0.489 \\
\hline White blood cells $\left(10^{3} / \mu \mathrm{l}\right)$ & $7.75 \pm 3.76$ & $7.31 \pm 2.54$ & 0.464 \\
\hline Red blood cells $\left(10^{6} / \mu \mathrm{l}\right)$ & $4.45 \pm 0.68$ & $4.63 \pm 0.71$ & 0.015 \\
\hline Platelets $\left(10^{3} / \mu \mathrm{l}\right)$ & $220.44 \pm 76.77$ & $201.73 \pm 62.39$ & 0.024 \\
\hline Hemoglobin $(\mathrm{mmol} / \mathrm{l})$ & $8.12 \pm 1.25$ & $8.29 \pm 1.22$ & 0.132 \\
\hline Hematocrit & $0.39 \pm 0.05$ & $0.40 \pm 0.05$ & 0.022 \\
\hline C-reactive protein $(\mathrm{mg} / \mathrm{l})$ & $8.09 \pm 20.48$ & $16.54 \pm 33.81$ & 0.131 \\
\hline $\begin{array}{l}\text { Aspartate transaminase } \\
(\mathrm{IU} / \mathrm{l})\end{array}$ & $24.70 \pm 14.64$ & $25.43 \pm 18.11$ & 0.693 \\
\hline $\begin{array}{l}\text { Alanine } \\
\text { aminotransferase (IU/l) }\end{array}$ & $21.88 \pm 15.67$ & $23.01 \pm 21.25$ & 0.946 \\
\hline $\begin{array}{l}\text { Total serum bilirubin } \\
(\mu \mathrm{mol} / \mathrm{l})\end{array}$ & $14.11 \pm 10.89$ & $13.38 \pm 7.42$ & 0.403 \\
\hline Total protein $(\mathrm{g} / \mathrm{l})$ & $69.95 \pm 6.62$ & $69.68 \pm 5.94$ & 0.520 \\
\hline Albumin $(\mathrm{g} / \mathrm{l})$ & $43.64 \pm 4.64$ & $42.82 \pm 4.37$ & 0.114 \\
\hline $\begin{array}{l}\text { Gamma-glutamyl } \\
\text { transpeptidase (IU/l) }\end{array}$ & $88.02 \pm 259.19$ & $77.94 \pm 140.54$ & 0.694 \\
\hline $\begin{array}{l}\text { Alkaline phosphatase } \\
\text { (IU/l) }\end{array}$ & $92.39 \pm 48.75$ & $106.84 \pm 165.61$ & 0.603 \\
\hline $\begin{array}{l}\text { Creatine phosphokinase } \\
\text { (IU/l) }\end{array}$ & $124.01 \pm 137.41$ & $126.94 \pm 149.25$ & 0.687 \\
\hline Uric acid $(\mu \mathrm{mol} / \mathrm{l})$ & $402.29 \pm 114.00$ & $385.01 \pm 99.02$ & 0.337 \\
\hline Urea $(\mathrm{mmol} / \mathrm{l})$ & $8.47 \pm 4.20$ & $8.98 \pm 5.06$ & 0.760 \\
\hline Cystatin $(\mathrm{mg} / \mathrm{L})$ & $1.48 \pm 0.69$ & $1.62 \pm 0.93$ & 0.654 \\
\hline Cholesterol $(\mathrm{mmol} / \mathrm{l})$ & $4.25 \pm 0.97$ & $4.35 \pm 1.34$ & 0.892 \\
\hline $\begin{array}{l}\text { Low-density lipoprotein } \\
(\mathrm{mmol} / \mathrm{l})\end{array}$ & $2.12 \pm 0.84$ & $2.21 \pm 1.06$ & 0.783 \\
\hline $\begin{array}{l}\text { High-density lipoprotein } \\
(\mathrm{mmol} / \mathrm{l})\end{array}$ & $1.37 \pm 0.43$ & $1.30 \pm 0.43$ & 0.225 \\
\hline $\begin{array}{l}\text { Activated partial } \\
\text { thromboplastin time (s) }\end{array}$ & $34.01 \pm 8.05$ & $33.00 \pm 5.78$ & 0.132 \\
\hline $\begin{array}{l}\text { International normalized } \\
\text { ratio }\end{array}$ & $1.08 \pm 0.24$ & $1.08 \pm 0.27$ & 0.467 \\
\hline Natrium $(\mathrm{mmol} / \mathrm{l})$ & $139.94 \pm 3.15$ & $140.39 \pm 2.71$ & 0.264 \\
\hline Kalium $(\mathrm{mmol} / \mathrm{l})$ & $4.66 \pm 0.48$ & $4.63 \pm 0.52$ & 0.641 \\
\hline Magnesium (mmol/l) & $0.70 \pm 0.13$ & $0.72 \pm 0.12$ & 0.160 \\
\hline Fibrinogen (mg/dl) & $362.77 \pm 109.28$ & $386.12 \pm 134.60$ & 0.177 \\
\hline Tacrolimus (ng/ml) & $9.40 \pm 3.83$ & $8.45 \pm 3.63$ & 0.037 \\
\hline $\begin{array}{l}\text { Mycophenolate mofetil } \\
(\mu \mathrm{g} / \mathrm{ml})\end{array}$ & $2.27 \pm 1.11$ & $2.24 \pm 1.22$ & 0.407 \\
\hline Cyclosporin (ng/ml) & $141.01 \pm 49.76$ & $110.60 \pm 32.04$ & 0.033 \\
\hline
\end{tabular}

SD: standard deviation.

Over ninety percent of patients in the cohort completed the follow-up. The cumulative survival rate is depicted in Figure 3.

Kaplan-Meier survival curves did not show statistically significant differences between those who received BBs and those who did not: $p=0.655$ (log-rank test). The Kaplan-Meier curves are shown in Figure 4.

Univariate Cox proportional hazard regression analysis revealed that the following parameters were associated with unfavorable prognosis: decreased albumin (g/l) HR: 0.87, 95\% CI (0.81-0.94), $p=0.0004$; increased fibrinogen $(\mathrm{mg} /$ dl) HR: 1.006 , 95\% CI (1.002-1.008), $p=0.0017$; and increased CRP (mg/l) HR: 1.014, 95\% CI (1.004-1.023), $p=0.0044$. Multivariate Cox proportional hazard regression model of survival did not show any significant predictors of death for any cause because the variables were too closely associated. The uni/multivariate Cox proportional hazard regression analysis is presented in Table 3.

\section{Discussion}

This paper has two major clinical implications. Firstly, the prognosis of the HTx patients who survived the in-hospital postoperative period in the eastern European country may 


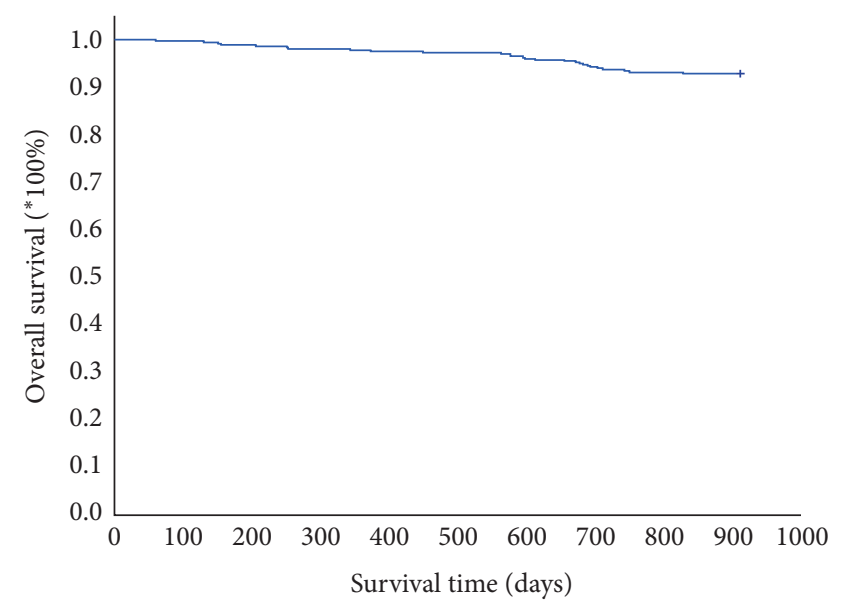

FIGURE 3: Survival probability of the patients fulfilling the inclusion criteria during the follow-up.

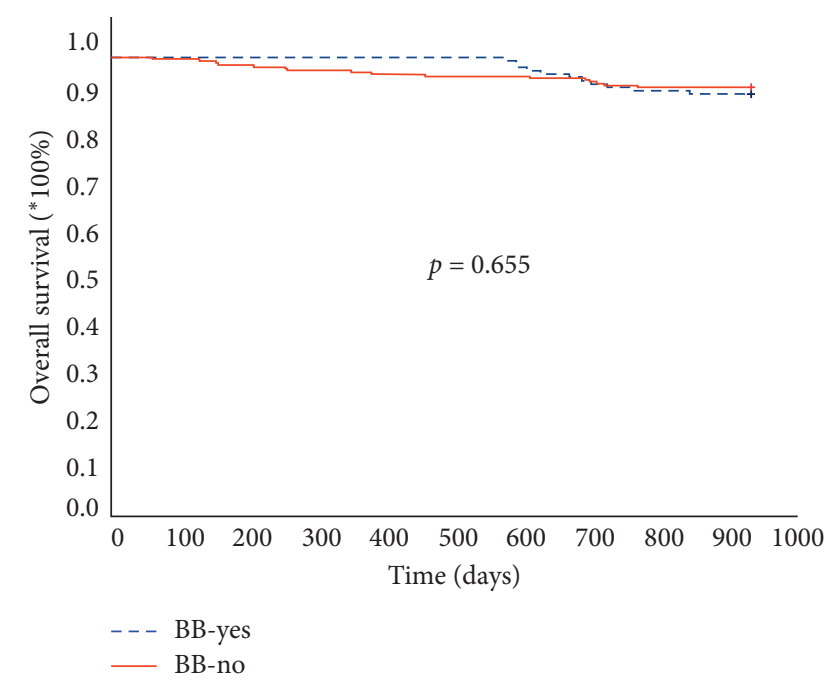

FIgURE 4: Kaplan-Meier survival curves depending on the beta blocker use during the follow-up.

not differ significantly from the western countries despite the substantial differences in the organization and funding of the healthcare systems $[8,9]$. Secondly, we could not document the beneficial effect of $\mathrm{BB}$ administration on survival in the real-life clinical setting. Several aspects might have played a role. These include the older age of the patients receiving BBs compared to the control group (56.94 \pm 14.68 vs. $52.70 \pm 15.35, p=0.008)$; the more complex clinical profile of patients with more than one indication for the therapy ( 94 patients $(68 \%)$ vs. 54 patients $(22 \%), p \leq 0.001)$; and the higher incidence of patients with the impairment of the systolic function of the heart (40 patients (29\%) vs. 30 patients $(12 \%), p \leq 0.001)$.

In our cohort, BBs were mainly initiated in the treatment of supraventricular and ventricular tachycardia and in patients with impaired LVEF. Moreover, we reported a large number of patients receiving atenolol $(n=24,17 \%)$ which has a lesser impact on hypertension, but not on heart rate, compared to bisoprolol [10-12]. The clinical practice at our center shows that BBs were introduced as a third or fourth line of drugs in the treatment of hypertension and frequently coadministered with calcium channel blockers (62 patients $(45 \%)$ vs. 85 patients $(35 \%), p=0.059)$; however, this difference was statistically insignificant. It is likely that using $\mathrm{BBs}$ in the cohort of older patients with higher incidence of comorbidities weakened or waived its potentially beneficial effect on survival $[13,14]$.

Ciarka et al. reported that BB treatment had beneficial effects on survival after HTx, which may be associated with its antiarrhythmic properties, especially given that it reduces the incidence of atrial fibrillation in the general population and after heart surgery [15-18]. In their study, patients receiving $\mathrm{BB}$ were older $(52 \pm 11$ years vs. $49 \pm 15$ years, $p=0.01)$ and had higher serum concentrations of total cholesterol (TC) $(216 \pm 53 \mathrm{vs.} 204 \pm 50 \mathrm{mg} / \mathrm{dl}$, $p=0.03$ ) and low-density lipoprotein cholesterol (LDL-C) $(120 \pm 44 \mathrm{mg} / \mathrm{dl}$ vs. $107 \pm 40 \mathrm{mg} / \mathrm{dl}, p=0.003)$. These results are in line with our observations. Patients receiving BBs in our study were also older $(56.94 \pm 14.68$ years vs. $52.70 \pm 15.35$ years, $p=0.008)$ and had higher concentrations of TC and LDL-C levels although without statistical significance $(4.35 \pm 1.34$ vs. $4.25 \pm 0.97 \mathrm{mmol} / \mathrm{l}$ and $2.21 \pm 1.06$ vs. $2.12 \pm 0.84 \mathrm{mmol} / \mathrm{l}, p=\mathrm{ns}$, respectively). We observed that the patients receiving BBs had different blood morphology which was expressed by elevated red blood cells (RBC) $\left(4.63 \pm 0.71\right.$ vs. $\left.4.45 \pm 0.68\left(10^{6} / \mu \mathrm{l}\right), p=0.015\right)$, elevated hematocrit $(0.40 \pm 0.05$ vs. $0.39 \pm 0.05, p=0.022)$, and decreased platelets $(201.73 \pm 62.39$ vs. $220.44 \pm 76.77$ $\left.\left(10^{3} / \mu \mathrm{l}\right), p=0.024\right)$. It was reported that the hemoglobin concentration and hematocrit are raised in hypertensive patients $[19,20]$. It has been proved in animal studies that the hemoglobin reduces the nitric oxide availability for the smooth muscle cells which implies vasoconstriction [21].

Despite the early controversies, there is a rising consensus that an increased heart rate stimulates coronary artery vasculopathy (CAV) and reduces survival after HTx [5-7, 22-26]. We found that the most advanced form of $\mathrm{CAV}$, according to the ISHLT recommendations, occurred more often in patients receiving BBs than those who did not ( $13 \%$ vs. $7 \%, p=0.073$ ), notwithstanding the difference was not statistically significant [27].

Nevertheless, it should be highlighted that the CAV, despite being present in half of the patients ten years after HTx, contributes only partially to the total mortality along with malignancies, infections, rejections, and renal insufficiencies $[28,29]$. This contribution tends to be even lower in centers providing careful follow-up with annual invasive assessments and early revascularization of narrow stenoses [30]. Therefore, we cannot provide substantial evidence that the use of BBs in the patients without effective heart rate reduction has a beneficial effect on survival. Moreover, with the positive impact of diltiazem and ivabradine on cardiac remodeling and exercise tolerance, it would be interesting to compare their efficacy alone or in combination; thus, further investigations are warranted [31-33]. 
TABLE 3: Uni/multivariate Cox regression analysis of risk factors.

\begin{tabular}{|c|c|c|c|c|c|c|}
\hline \multirow{2}{*}{$\begin{array}{l}\text { Cox regression } \\
\text { Risk factor }\end{array}$} & \multicolumn{3}{|c|}{ Univariate } & \multicolumn{3}{|c|}{ Multivariate } \\
\hline & HR & $95 \%$ CI & $p$ & HR & 95\% CI & $p$ \\
\hline Beta blocker: yes & 0.54 & $(0.28-1.44)$ & 0.2820 & 0.65 & $(0.22-1.93)$ & 0.4342 \\
\hline CRP (mg/l) & 1.014 & $(1.004-1.023)$ & 0.0044 & 1.011 & $(0.999-1.023)$ & 0.0667 \\
\hline Albumin (g/l) & 0.87 & $(0.81-0.94)$ & 0.0004 & 0.98 & $(0.86-1.12)$ & 0.8006 \\
\hline Fibrinogen (mg/dl) & 1.006 & $(1.002-1.008)$ & 0.0017 & 1.005 & $(1.000-1.010)$ & 0.0675 \\
\hline
\end{tabular}

CI: confidence interval; CRP: C-reactive protein; HR: hazard ratio.

4.1. Limitations of the Study. The study is limited by the fact that only a part of the population of HTx patients has been analyzed due to technical reasons related to the automatic data acquisition. Moreover, we did not address the diastolic function of the heart and immunological agents which could have influenced the results.

\section{Conclusions}

The use of BB in our cohort of patients after HTx was not associated with improved survival. Further investigations including the use of other HR-decreasing agents like ivabradine or diltiazem, alone or in combination with $\mathrm{BBs}$, are mandatory in the HTx patient population.

\section{Data Availability}

The data used to support the findings of this study are restricted by the local ethical board (approval number ŚIL.KB.790.19) in order to protect patient privacy. Data are available from the corresponding author through gkubiak@ sccs.pl for researchers who meet the criteria for access to confidential data.

\section{Additional Points}

The free trial version of the ProjectRetrieval ${ }^{\circledR}$ software is available to download at the http://retrieval-project.com.pl. Its functionality is limited. Any potential users are kindly requested to contact the authors prior to the use of the software in order to set a consensus considering the donation and citation details.

\section{Conflicts of Interest}

The authors declare that they have no conflicts of interest.

\section{Acknowledgments}

The authors thank Mrs. Wiktoria Świątek for the English language editing and Dr. Kuczaj and Dr. Małyszek-Tumidajewicz for providing careful care in the outpatient clinic. They would like to express their special acknowledgments to Prof. Zakliczyński for the experience and invaluable remarks he shared. The publication of the manuscript was funded by the Medical University of Silesia.

\section{References}

[1] F. Buendia-Fuentes, L. Almenar, C. Ruiz et al., "Sympathetic reinnervation 1 year after heart transplantation, assessed using iodine-123 metaiodobenzylguanidine imaging," Transplantation Proceedings, vol. 43, no. 6, pp. 2247-2248, 2011.

[2] S.-R. Lee, D.-Y. Kang, Y. Cho et al., "Early parasympathetic reinnervation is not related to reconnection of major branches of the vagus nerve after heart transplantation," Korean Circulation Journal, vol. 46, no. 2, pp. 197-206, 2016.

[3] R. S. Bexton, J. R. Milne, R. Cory-Pearce, T. A. English, and A. J. Camm, "Effect of beta blockade on exercise response after cardiac transplantation," Heart, vol. 49, no. 6, pp. 584-588, 1983.

[4] S. S. Kushwaha, N. R. Banner, N. Patel, A. Cox, H. Patton, and M. H. Yacoub, "Effect of beta blockade on the neurohumoral and cardiopulmonary response to dynamic exercise in cardiac transplant recipients," Heart, vol. 71, no. 5, pp. 431-436, 1994.

[5] R. Rivinius, M. Helmschrott, A. Ruhparwar et al., "Control of cardiac chronotropic function in patients after heart transplantation: effects of ivabradine and metoprolol succinate on resting heart rate in the denervated heart," Clinical Research in Cardiology, vol. 107, no. 2, pp. 138-147, 2018.

[6] M. Liebo, J. Newman, A. Joshi et al., "Elevated heart rate following heart transplantation is associated with increased graft vasculopathy and mortality," Journal of Cardiac Failure, vol. 25, no. 4, pp. 249-256, 2019.

[7] M. Pazdernik, D. Wichterle, Z. Chen et al., "Heart rate and early progression of cardiac allograft vasculopathy: a prospective study using highly automated 3-D optical coherence tomography analysis," Clinical Transplantation, vol. 34, no. 2, Article ID e13773, 2020.

[8] L. E. Zijlstra, A. A. Constantinescu, O. Manintveld et al., "Improved long-term survival in Dutch heart transplant patients despite increasing donor age: the Rotterdam experience," Transplant International, vol. 28, no. 8, pp. 962-971, 2015.

[9] T. Deuse, F. Haddad, M. Pham et al., "Twenty-year survivors of heart transplantation at stanford university," American Journal of Transplantation, vol. 8, no. 9, pp. 1769-1774, 2008.

[10] J. M. Neutel, D. H. G. Smith, C. V. S. Ram, M. P. Lefkowitz, M. K. Kazempour, and M. A. Weber, "Comparison of bisoprolol with atenolol for systemic hypertension in four population groups (young, old, black and nonblack) using ambulatory blood pressure monitoring," The American Journal of Cardiology, vol. 72, no. 1, pp. 41-46, 1993.

[11] R. Lewis, D. Maclean, C. Ioannides, A. Johnston, and D. McDevitt, "A comparison of bisoprolol and atenolol in the treatment of mild to moderate hypertension," British Journal of Clinical Pharmacology, vol. 26, no. 1, pp. 53-59, 1988. 
[12] W.-J. Zhou, R.-Y. Wang, Y. Li et al., "A randomized controlled study on the effects of bisoprolol and atenolol on sympathetic nervous activity and central aortic pressure in patients with essential hypertension," PLoS ONE, vol. 8, no. 9, Article ID e72102, 2013.

[13] M. R. Costanzo, A. Dipchand, R. Starling et al., "The international society of heart and lung transplantation guidelines for the care of heart transplant recipients," The Journal of Heart and Lung Transplantation: The Official Publication of the International Society for Heart Transplantation, vol. 29, no. 8, pp. 914-956, 2010.

[14] M. R. Mehra, C. E. Canter, M. M. Hannan et al., "The 2016 international society for heart lung transplantation listing criteria for heart transplantation: a 10-year update," The Journal of Heart and Lung Transplantation, vol. 35, no. 1, pp. 1-23, 2016.

[15] A. Ciarka, L. H. Lund, J. Van Cleemput, G. Voros, W. Droogne, and J. Vanhaecke, "Effect of heart rate and use of beta blockers on mortality after heart transplantation," The American Journal of Cardiology, vol. 118, no. 12, pp. 19161921, 2016.

[16] H. Fröhlich, L. Torres, T. Täger et al., "Bisoprolol compared with carvedilol and metoprolol succinate in the treatment of patients with chronic heart failure," Clinical Research in Cardiology, vol. 106, no. 9, pp. 711-721, 2017.

[17] G. Marazzi, F. Iellamo, M. Volterrani et al., "Comparison of effectiveness of carvedilol versus bisoprolol for prevention of postdischarge atrial fibrillation after coronary artery bypass grafting in patients with heart failure," The American Journal of Cardiology, vol. 107, no. 2, pp. 215-219, 2011.

[18] M. Konishi, G. Haraguchi, S. Kimura et al., "Comparative effects of carvedilol vs bisoprolol for severe congestive heart failure," Circulation Journal, vol. 74, no. 6, pp. 1127-1134, 2010.

[19] M. Emamian, S. M. Hasanian, M. Tayefi et al., "Association of hematocrit with blood pressure and hypertension," Journal of Clinical Laboratory Analysis, vol. 31, no. 6, Article ID e22124, 2017.

[20] S.-G. Lee, J. H. Rim, and J.-H. Kim, "Association of hemoglobin levels with blood pressure and hypertension in a large population-based study: the Korea National Health and Nutrition Examination Surveys 2008-2011," Clinica Chimica Acta, vol. 438, pp. 12-18, 2015.

[21] P. Cabrales, G. Han, P. Nacharaju, A. J. Friedman, and J. M. Friedman, "Reversal of hemoglobin-induced vasoconstriction with sustained release of nitric oxide," American Journal of Physiology-Heart and Circulatory Physiology, vol. 300, no. 1, pp. H49-H56, 2011.

[22] L. Gullestad, H. Ross, J. Myers et al., "Importance of decreased heart rate in predicting transplant coronary artery disease," Clinical Transplantation, vol. 11, no. 6, pp. 628-632, 1997.

[23] L. A. Weinrauch and J. A. D'Elia, "Use of calcium channel blockers after heart transplantation," The American Journal of Cardiology, vol. 120, no. 3, p. 512, 2017.

[24] A. B. Shah, J. K. Patel, M. Rafiei, R. P. Morrissey, M. M. Kittleson, and J. A. Kobashigawa, "The impact of mean first-year heart rate on outcomes after heart transplantation: does it make a difference?" Clinical Transplantation, vol. 27, no. 5, 2013.

[25] Á. López-Sainz, E. Barge-Caballero, G. Barge-Caballero et al., "Late graft failure in heart transplant recipients: incidence, risk factors and clinical outcomes," European Journal of Heart Failure, vol. 20, no. 2, pp. 385-394, 2018.
[26] J. Schilling and J. Vader, "Be still my beating heart: should heart rate be a target of therapy after heart transplantation?" Journal of Cardiac Failure, vol. 25, no. 4, pp. 257-258, 2019.

[27] M. R. Mehra, M. G. Crespo-Leiro, A. Dipchand et al., "International society for heart and lung transplantation working formulation of a standardized nomenclature for cardiac allograft vasculopathy-2010," The Journal of Heart and Lung Transplantation, vol. 29, no. 7, pp. 717-727, 2010.

[28] M. J. Wilhelm, "Long-term outcome following heart transplantation: current perspective," Journal of Thoracic Disease, vol. 7, no. 3, pp. 549-551, 2015.

[29] L. H. Lund, L. B. Edwards, A. Y. Kucheryavaya et al., "The registry of the international society for heart and lung transplantation: thirty-first official adult heart transplant report-2014; focus theme: retransplantation," The Journal of Heart and Lung Transplantation, vol. 33, no. 10, pp. 996-1008, 2014.

[30] H. R. C. Biefer, S. H. Sündermann, M. Y. Emmert et al., "Surviving 20 years after heart transplantation: a success story," The Annals of Thoracic Surgery, vol. 97, no. 2, pp. 499-504, 2014.

[31] S. Varnado, Y. Peled-Potashnik, A. Huntsberry et al., "Effect of diltiazem on exercise capacity after heart transplantation," Clinical Transplantation, vol. 31, no. 8, Article ID e12997, 2017.

[32] E. Lage-Gallé, N. Romero-Rodríguez, J. Nevado-Portero et al., "Safety and effectiveness of ivabradine after cardiac transplantation," Transplantation Proceedings, vol. 42, no. 8, pp. 3191-3192, 2010.

[33] A. Doesch, S. Mueller, C. Gleissner et al., "Heart rate reduction for 36 months with ivabradine reduces left ventricular mass in cardiac allograft recipients: a long-term follow-up study," Drug Design, Development and Therapy, vol. 7, pp. 1323-1328, 2013. 